\title{
Current measures to maintain the stability of workers in Slovak companies
}

\author{
Jana Kissová $^{1 *}$, Gabriela Dubcová ${ }^{2}$
}

\begin{abstract}
Over a short period of time, individual countries in the world face a common problem that affects them and adversely affects the lives of individuals. In connection with the current emergency situation related to the corona virus pandemic, it is possible to notice fundamental changes and enormous impact in the social or economic dimension. The aim of the article is to provide an overview of the current situation in selected countries and to compare the system of measures in the Slovak Republic and the Czech Republic that were adopted in order to stabilize or retain workers or aimed at elimination of imminent damage.
\end{abstract}

\section{Introduction}

Over a short period of time, individual countries in the world face a common problem that affects them and adversely affects the lives of individuals. In connection with the current emergency situation related to the corona virus pandemic, it is possible to notice fundamental changes and enormous impact in the social or economic dimension. In the fight against the "invisible enemy", countries are taking different kinds of measures to protect the health of all their people. Procedures, steps, regulations or restrictions are adopted autonomously based on their own decisions and estimates of the development of the situation.

The aim of the article is to provide an overview of the current situation in selected countries and to compare the system of measures in the Slovak Republic and the Czech Republic that were adopted in order to stabilize or retain workers or aimed at elimination of imminent damage.

\subsection{Theoretical bases related to the stabilization of workers}

Stabilization of workers is the subject of human resources research - generally called human resources. For the sake of prosperity, the goal of any business is to retain and stabilize workers. For this purpose, each company has defined stabilization measures, which may vary depending on the decision and discretion of the company managers. [2, 13]

At the time of the current crisis, the set of measures to retain workers is fundamentally changing as it affects a large number of businesses and people. Therefore, whether they are kept in their positions or not in a given situation depends on the decisions of the state or the extent of the support the state will provide and how it will be implemented. $[1,3]$

\footnotetext{
*Corresponding authors: jana.kissova@euba.sk, gabriela.dubcova@euba.sk
} 


\subsection{Overview of the current situation and measures taken in selected countries to limit the spread of coronavirus}

Among the countries of Europe, Italy was the most affected by corona virus, gradually followed by other above mentioned countries. The way and extent of financing of the adopted measures is preliminary, as it may change in the light of developments.

An overview of the adopted measures in the selected countries is illustrated in Table 1 below, which sets out the scope and funding of the adopted measures. The common objective of the measures is to stop the spread of the virus as quickly as possible and to eliminate the damage.

Table 1. Overview and comparison of adopted measures in the most affected countries of Europe

\begin{tabular}{|c|c|c|c|}
\hline Germany & Italy & Spain & France \\
\hline $\begin{array}{c}\text { The State } \\
\text { Development Bank } \\
\text { KfW provides } \\
\text { loans. } \\
\text { Total volume } 500 \\
\text { bil. Eur. }\end{array}$ & $\begin{array}{l}\text { Money to support } \\
\text { hospitals } \\
\text { (3.5 bil. Eur. ). }\end{array}$ & $\begin{array}{l}\text { Guarantees of } 100 \\
\text { billion Eur. for } \\
\text { loans to } \\
\text { businesses. }\end{array}$ & $\begin{array}{c}\text { Funds to support } \\
\text { employment } \\
\text { (estimated Eur. } 45 \\
\text { billion) }\end{array}$ \\
\hline $\begin{array}{l}600 \text { bil. Eur. to } \\
\text { help companies is } \\
\text { under preparation }\end{array}$ & $\begin{array}{l}\text { Subsidies for } \\
\text { those who still } \\
\text { have to work and } \\
\text { are in high-risk } \\
\text { employment } \\
\text { environment. }\end{array}$ & & \\
\hline $\begin{array}{l}\text { Aid from the } \\
\text { government to } \\
\text { exporters. }\end{array}$ & $\begin{array}{c}\text { Support for } \\
\text { companies (Eur. } 10 \\
\text { billion). }\end{array}$ & $\begin{array}{l}\text { Deferment of } \\
\text { mortgage and } \\
\text { loan } \\
\text { repayments for } \\
\text { people who } \\
\text { cannot work. }\end{array}$ & $\begin{array}{l}\text { Deferred } \\
\text { payment of taxes } \\
\text { for companies. }\end{array}$ \\
\hline $\begin{array}{l}\text { Help for companies } \\
\text { to maintain } \\
\text { employment while } \\
\text { employees are at } \\
\text { home through the } \\
\text { Kurzarbeitergeld. }\end{array}$ & $\begin{array}{c}\text { Support for parents } \\
\text { who have to stay } \\
\text { home with their } \\
\text { children. }\end{array}$ & $\begin{array}{l}\text { Some social aid } \\
\text { benefits will be } \\
\text { suspended and } \\
\text { redistributed in } \\
\text { favor of } \\
\text { vulnerable } \\
\text { population } \\
\text { groups. }\end{array}$ & $\begin{array}{l}\text { Support for } \\
\quad \text { parents } \\
\text { who need to stay } \\
\text { home with their } \\
\quad \text { children }\end{array}$ \\
\hline $\begin{array}{l}\text { Deferred taxes are } \\
\text { planned for } \\
\text { companies. }\end{array}$ & $\begin{array}{l}\text { One-time support } \\
\text { of EUR } 500 \text { for } \\
\text { sole traders. }\end{array}$ & $\begin{array}{l}\text { Introduction of } \\
\text { so-called } \\
\text { institute of } \\
\text { temporary } \\
\text { release from } \\
\text { work. } \\
\end{array}$ & $\begin{array}{l}300 \text { billion Eur in } \\
\text { the form of } \\
\text { guarantees for the } \\
\text { banking sector to } \\
\text { help companies. }\end{array}$ \\
\hline
\end{tabular}

Source: Financial Times

\section{Aim}

The aim of the article is to provide an overview of the current situation related to the spread of coronavirus in individual countries. The priority is to identify and compare the adopted measures to support and maintain employment in the Slovak Republic and the Czech Republic. 


\section{Results and discussion}

The subject of this section is to provide an overview of measures that are aimed to help with maintaining stability and providing support for employment in connection with the spread of coronavirus in Slovakia and to compare them with the measures adopted in the Czech Republic.

\subsection{The system of adopted measures in Slovakia and in the Czech Republic related to the current situation}

Due to the emergency situation, the Government of the Slovak Republic took vigorous measures almost at the beginning. Implementation of measures to prevent the spread of coronavirus was slower and more moderate in the Czech Republic, which was reflected in a faster increase in the number of infected patients and unfortunately also in the number of deaths. Currently, the measures taken in both countries are extreme. As the impact of these measures has a significant negative effect on the further functioning of the economy or the quality of life of the population, they consequently require a set of measures to mitigate these impacts.

General immediate and strict measures were taken mainly to protect the health of the citizens. Although they can be perceived as a major intervention in the way of life and quality - the priority is to prevent the spread of the virus in the shortest possible time and to ensure the protection of public health. Specific decisions were implemented on an ongoing basis in rapid succession as the situation evolved.

\subsubsection{The system of measures to retain workers in the SR related to the current situation.}

The strict measures concerning the compulsory closure of various types of services have undoubtedly and within a very short time period caused unfavorable and fundamental problems in the country's economy, industry or the business sector. According to experts and analysts, this situation will cause a temporary deep downturn and a high deficit, but a very rapid rebound after the crisis has subsided. The current situation represents "stopping or freezing" of almost all economic activities.

In addition to the economic impact, strict measures also have an impact on the overall level and quality of life of citizens as well as on the labor market and employment. In order to overcome the emergency situation and to maintain an acceptable standard of living for people and workers, the Slovak Republic is preparing legislative changes in the area of business and employment policy to help employers maintain the job positions for their employees. These changes will be incorporated into the amendment to the Social Insurance Act and also into the amendment to the Employment Services Act.

The changes will concern several groups in the labor market, such as employers (legal persons), employees or sole traders (self-employed) etc. They will be implemented with the aim to alleviate the unfavorable situation for these group, since they are not responsible for it. The following are the measures presented so far to mitigate the impact of the crisis for the three groups mentioned above in order to maintain and promote employment.

A. The following measures are prepared for employers: [6 - 8, 10 - 12]

$\circ \quad$ JobKeeper payment - it aims to prevent redundancies and to simplify the conditions for recruitment

$\circ \quad$ deferred payment of health and social aid contributions - deferment of the obligation to pay health and social contributions for the employer (not for the employee) for the 
months of February, March and April 2020, without entry in the register of defaulters or other sanctions. Payments for May would be due without deferment (in June). The amount of the temporarily unpaid contributions will be subsequently calculated free of interest and divided into 18 monthly installments, which will be payable from July 2020 to December 2021

$\circ \quad$ cancellation of the obligation to pay corporate income tax advance payments cancellation of the obligation to pay corporate income tax advance payments by June 30, 2020 (i.e. the next advance payments will be payable from October 2020). Interests on late payments or other sanctions will be waived and the missed advance payments will be reflected in the annual accounts.

$\circ \quad$ deferment of VAT for three months - deferment of VAT for February, March and April 2020. VAT for May would be payable in due time (25 June) without any sanctions. The amount of the temporarily unpaid VAT will then be alculated interestfree and divided into 18 monthly installments, which will be payable from July 2020 to December 2021. It applies only to retail and service establishments (according to measure No. OPL / 2596/2020 ÚVZ SR), as well as to specific justified cases (for example, companies that supply exclusively to retail or prove that they were directly affected by the coronavirus-related situation) and those operations that have been affected by the closure of schools (such as private nurseries)

- reimbursement of salary for an employee without allocated work (20-20-60) over a period of three months - if the employer is unable to allocate work to the employee during the months of April, May, June, due to the coronavirus situation, he may order him to take time off, paying him a salary of $80 \%$ of his average salary in proportion to: $-20 \%$ will be paid by the employer, $-60 \%$ will be paid by the Social Insurance Agency

- wage for "home office"- if the employee works from home, he / she is entitled to the wage in full

○ priority completion of VAT inspections and refunds without delays - Priority completion of VAT inspections where a taxpayer has applied for a VAT refund. Allocataion of an amount of $€ 10,000$ to be rejected or paid no later than 30.04. and the amount of $€ 50$ thousand, which must be rejected or paid by 31.05. If the tax office did not find any disparities during the inspection within the above-mentioned deadlines for which VAT can be withheld, it must pay it back immediately. This does not concern the period for carrying out tax audits, which is one year.

B. The following measures are prepared for employees: [6 - 8, 10 - 12]

- entitlement to "pandemic" nursing care - in the case of quarantine or home isolation, it is proposed to extend the period of disbursement of nursing care for children up to 11 years of age or 18 years of age for children with long-term adverse health conditions for the whole period of quarantine and isolation, as well as during the entire closure of schools and pre-school facilities,

- adjustment of sick pay - the employer paid the amount of sick pay for the first 10 days up to now; from the first day of the quarantine period, it will be reimbursed by a social insurance company amounting to $55 \%$ of the daily assessment base

- filing an application for inclusion in the job seekers register by electronic means without a qualified electronic signature 
C. The following measures are prepared for entrepreneurs: [12]

- Possibility to defer the obligation to file tax declaration and the obligation to pay income tax till 30.6 for all entrepreneurs - tax declarations and tax payment defferal has already been approved

- Payments of minimum contributions will be forgiven for a period of three months. for sole traders who shall pay more than minimum contributions, only the amount of minimum contributions would be forgiven.

- Suspension of trade for sole traders for at least one month or for an indefinite period - possibility to suspend trade for at least one month (currently 6 months), for an indefinite period but for a maximum of three years.

The most recent steps in the area of employment support include the specific measures especially for employees, smaller companies or sole traders, listed in Table 2:

Table 2. Program: "First Aid to Employees, Companies and Sole Traders"

\begin{tabular}{|c|c|}
\hline Measure & Method of support \\
\hline $\begin{array}{l}\text { The state pays } 80 \% \text { of } \\
\text { the employee's salary }\end{array}$ & $\begin{array}{l}\text { in companies whose operations have been compulsorily } \\
\text { closed. Those employees who stayed at home will receive } \\
\text { wages from the state. } \\
\text { they will not cost anything for the employer. The payment } \\
\text { will also include tax per employee and contributions per } \\
\text { employee. The amount of the contribution will have its } \\
\text { financial ceiling as well as other eligibility conditions. }\end{array}$ \\
\hline $\begin{array}{l}\text { Contributions for sole } \\
\text { traders and employees }\end{array}$ & $\begin{array}{l}\text { in companies that have seen a drop in sales, it will depend } \\
\text { on how much they were affected. Calculations for March } \\
\text { will be halved. } \\
\text { in the case of April: } \\
\circ \quad \text { if sales drop by more than } 20 \text { percent, the state will } \\
\text { contribute } 180 \text { euros to salaries. } \\
\text { with a drop of more than } 40 \text { percent, the state will } \\
\text { contribute } 300 \text { euros. } \\
\text { with a drop of } 60 \text { percent, it will be } 420 \text { euros, } \\
\circ \quad \text { with a drop of more than } 80 \% \text {, the state will contribute } \\
540 \text { euros. }\end{array}$ \\
\hline $\begin{array}{c}\text { Provision of bank } \\
\text { guarantees worth half a } \\
\text { billion euros }\end{array}$ & $>$ for companies to be able to finance their business \\
\hline $\begin{array}{l}\text { Reimbursement of } \\
\text { wages }\end{array}$ & $\begin{array}{l}\text { Employees in quarantine and parents taking care of a family } \\
\text { member will be paid } 55 \text { percent from their gross wage. } \\
\text { this measure was approved by the government and } \\
\text { parliament during the week }\end{array}$ \\
\hline $\begin{array}{l}\text { Deferred payments of } \\
\text { contributions }\end{array}$ & $>$ when sales drop by more than 40 percent \\
\hline $\begin{array}{l}\text { Deferred income tax } \\
\text { advance payments }\end{array}$ & $\begin{array}{l}\text { when sales drop by more than } 40 \text { percent } \\
\text { Entrepreneurs will start to pay advance payments since } \\
\text { October }\end{array}$ \\
\hline $\begin{array}{l}\text { Possibility to deduct } \\
\text { losses from previous } \\
\text { years }\end{array}$ & $\begin{array}{l}2 \text { companies will be allowed to deduct losses from the year } \\
2014 \text { (including) } \\
\text { It is only applicable for companies who haven't deducted } \\
\text { the losses yet }\end{array}$ \\
\hline
\end{tabular}

Source: processed according to [9] 


\subsubsection{The system of measures to retain workers in the Czech Republic related to the current situation.}

In comparison with Slovakia, there is a broader range of measures applied in the Czech Republic in the framework of "support programs", which specify the situations or the conditions under which they will be provided.

A. The following measures have been taken for employers: [5]

○ Antivirus - Employment Promotion - employment protection program to help protect jobs, the state will use it to compensate for money paid. It is intended to help employers better cope with the current situation without having to make redundancies. To become eligible for the program depends on specific situations:

Table 3. Employment promotion program according to specific situation

\begin{tabular}{|c|c|}
\hline Sitution & Method of support \\
\hline Quarantine order for employees & $\begin{array}{l}\text { the employee receives a wage } \\
\text { compensation of } 60 \% \text { of the average } \\
\text { reduced earnings } \\
\text { contribution for the employer } \\
\text { 'amounting to the full salary } \\
\text { compensation }\end{array}$ \\
\hline $\begin{array}{l}\text { Obstacles to work on the part of } \\
\text { the employer due to the obligation } \\
\text { to close operations due to the } \\
\text { emergency situation }\end{array}$ & $\begin{array}{l}\text { the employee receives } 100 \% \text { of the } \\
\text { average earnings } \\
\text { contribution for the employer } \\
\text { 'amounting to } 80 \% \text { of paid salary } \\
\text { compensation }\end{array}$ \\
\hline $\begin{array}{l}\text { Obstacles to work on the part of } \\
\text { the employer due to quarantine } \\
\text { order or child care in significant } \\
\text { proportion of employees }(30 \%)\end{array}$ & $\begin{array}{l}>\text { the employee receives } 100 \% \text { of the } \\
\text { average earnings } \\
>\text { Contribution for the employer } \\
\text { 'amounting to } 80 \% \text { of paid salary } \\
\text { compensation }\end{array}$ \\
\hline $\begin{array}{l}\text { Limited availability of inputs (raw } \\
\text { material, products, services) } \\
\text { necessary for operations }\end{array}$ & $\begin{array}{l}\text { the employee receives } 80 \% \text { of the } \\
\text { average earnings } \\
\text { Contribution for the employer } \\
\text { 'amounting to } 50 \% \text { of paid salary } \\
\text { compensation }\end{array}$ \\
\hline $\begin{array}{l}\text { Reduction in the demand for } \\
\text { services, manufacturing and other } \\
\text { products of the company }\end{array}$ & $\begin{array}{l}\text { the employee receives } 60 \% \text { of the } \\
\text { average earnings } \\
\text { Contribution for the employer } \\
\text { 'amounting to } 50 \% \text { of paid salary } \\
\text { compensation }\end{array}$ \\
\hline
\end{tabular}

Source: processed according to [5]

B. The following measures have been taken for employees [4]:

Within the framework of labor - law relations, the so - called. "Labor Ten Commandments for handling Coronavirus in Czech Republic", have been issued which define in detail the material security of employees according to specific situations.

- Wage compensation - for the first 14 calendar days, the employee is entitled to get a wage compensation of $60 \%$ of reduced average income. From the 15 th calendar day, the sickness pay is paid to an employee who is in quarantine, to an employee who was acknowledged as temporarily incapable of work due to illness, due to the 
temporary closure or restriction of operations as a result of emergency measures imposed by the public health authority,

- Nursing care - belongs to an employee who cares for a child up to the age of 13 or from the age of 13 with the first degree of dependence for the whole time of closing the school facility

$\circ$ Wage compensation of $100 \%$ of average income - belongs to the remaining employees due to the absence of most employees (e.g due to quarantine, childcare...)

$\circ \quad$ Wage compensation of $80 \%$ of average income - belongs to employees as a result of restrictions in inputs (supplies of raw materials, services, components...)

- Wage compensation of $100 \%$ of average income - belongs to employees due to temporary closure or restriction of operations (e.g clothing stores) or because of a reduction in demand for services or products

○ Home office wage (home office) - if the employee works from home, he / she is entitled to the full wage

C. The following measures have been taken for sole traders: [5]

- possibility to defer filing of the income and expenditure statement - entrepreneurs can submit it without sanctions until 03.08.2020. In case also the insurance premium has been paid till this date, the enterpreuner will not be penalized for late payment.

- forgiveness of social insurance - entrepreneurs will not have to pay the specified premiums from March to August, thus reducing their total premiums by the amount corresponding to the minimum pension prepayments for half a year. Sole traders will not have to pay anything at all. The period will be added to the pension entitlements.

- Suspension or termination of trade license, registration at the Labor Office of Czech Republic - To terminate a business activity, it is necessary to notify the relevant authority in writing (electronically) and to register with the Labor Office.

$\circ$ deferred income tax declaration - Deferred income tax declarations till 1.07.2020 for all legal and natural persons.

o individual remission of a fine for late payment of all taxes - in cases where the taxpayer proves the reasons related to coronaviruses.

$\circ$ final phase of EET deferment (deferment in the last phase of implementation of electronic sales registration) - the original date is postponed by 3 months until 1 August. During this time the Financial and Customs Administration will proceed with maximum tolerance and will operate only in advisory function.

\section{Conclusion}

The situation concerning the spreading of corona virus is constantly evolving. Individual countries are affected differently. From the current situation and development it is clear that countries that underestimated this disease at the beginning and took only mild and moderate measures are currently hit the most with a high death rate. It appears that strict measures that prioritize health over the prosperity of the economy are necessary to be able to manage and overcome the crisis.

The article provides an overview of measures taken to mitigate the crisis in some countries. It focuses more on the system of measures adopted for individual groups of the labor market in order to maintain jobs in the Slovak and Czech Republic. Based on the comparison, it can be stated that the Czech Republic has adopted a broader set of measures, while in the Slovak Republic the measures are formed at a slower pace due to the need for legislative changes, amendments to laws and the current change of government. Several of the measures mentioned to be taken in the Slovak Republic are still in the process of being 
negotiated, i.e they may not be adopted eventually. To conclude, it should be noted that these measures cannot be considered as definitive, they will be modified, amended or supplemented in the coming weeks, depending on the evolution of the situation.

\section{Acknowledgement}

This paper is an outcome of projects: „Stabilization on Human Capital in Slovak Enterprises as an Immanent Determinant of their Success, Competitiveness and Sustainable Development “, VEGA No. 1/0569/18 - funded by the University of Economics in Bratislava; led by doc. Ing. Mgr. Gabriela Dubcová, PhD. - project share is $100 \%$.

\section{References}

1. H. Huettermann - H. Bruch (2019). Mutual profits? HRM in health, collective wellbeing and organizational performance. Journal of Managemet Studies, vol. 56, No.6 pp.1405-1072

2. K. Burdett - C. C. Tudela - M. Coles (2020). The cost of Jobs Loss. The Review of Economics Studies. No. 1/2020 ISSN 0034-6527

3. M. Vooren at.al. (2018). The Effectiveness of active labor market polices, Journal of Economics Survey, vol. 33, No.1, pp. 125-149

4. Ministerstvo financií Českej republiky. Ministersvo financí prěhledne ke koronaviru. (1903.2020) Dostupné na: https:/www.mfcr.cz/cs/aktualne/koronavirus-covid19/2020/ministerstvo-financi-prehledne-ke-korona-37925 [accessed 28.03.2020]

5. Ministerstvo práce a sociálních věcí Českej republiky. Informace ke koronaviru. Dostupné na: https://www.mpsv.cz/web/cz/zamestnanci-info [accessed 28.03.2020]

6. N. Seneši. Príspevok na podporu udržania pracovných miest v roku 2020. (23.3.2020) Dostupné na: https://www.podnikajte.sk/financie-na-podnikanie/prispevok-napodporu-udrzania-pracovnych-miest-2020 [accessed 28.03.2020]

7. N. Seneši. Predíži sa kvôli koronavírusu termín na podanie daňových priznaní? (13.03.2020) Dostupné na: https://www.podnikajte.sk/dan-z-prijmov/predlzi-sa-kvolikoronavirusu-termin-na-podanie-danovych-priznani [accessed 28.03.2020]

8. Poslanci schválili zavedenie pandemického ošetrovného a poskytovanie príspevkov na udržanie pracovných miest. (25.032020) Dostupné na:

https://denniks.sk/32208/poslanci-schvalili-zavedenie-pandemickeho-osetrovneho-aposkytovanie-prispevkov-na-udrzanie-pracovnych-miest/ [accessed 28.03.2020]

9. Prvá pomoc pre zamestnancov či firmy. Pozrite si prehl'ad siedmich ekonomických opatrení (29.03.2020) Dostupné na: https://index.sme.sk/c/22370764/povedali-akochcu-pomoct-firmam-a-zivnostnikom-pozrite-si-prehlad.html?ref=FB [accessed 28.03.2020]

10. V. Folentová - M. Barcíková. Aktuálny zoznam návrhov na pomoc podnikom, o ktorom koalícia rokuje. (27.03.2020) Dostupné:

https://e.dennikn.sk/1825413/aktualny-zoznam-navrhov-na-pomoc-podnikom-oktorom-koalicia-rokuje/?ref=side\&_ga=2.101082945.1124802050.1585333719841732987.1583937711 [accessed 28.03.2020]

11. Vláda schválila pandemické ošetrovné a d’alšie sociálne opatrenia. Pozrite si ich prehl'ad. (25.03.2020) Dostupné na: https://finweb.hnonline.sk/ekonomika/2119105vlada-schvalila-pandemicke-osetrovne-a-dalsie-socialne-opatrenia-pozrite-si-ichprehlad [accessed 28.03.2020]

12. Z. Kollárová. Vláda odobrila odloženie daní do konca júna, spísané sú aj d'alšie opatrenia (18.03.2020) Dostupné na: https://e.dennikn.sk/1808736/vlada-odobrilaodlozenie-dani-do-konca-juna-spisane-su-aj-dalsie-opatrenia/ [accessed 28.03.2020] 
13. Z. K. Chulanova (2019). Profesional standards as factor of daptation of human resources to the industry 4.0 Aproaches to development and impelementation, Journal of Human Resource Management, vol. XXII, No.1/2019, 12-20 ISSN 2453-7683

\section{Contact}

Ing. Jana Kissová, PhD.

University of Economics in Bratislava, Faculty of Business Management

Main Street No. 1, 85235 Bratislava, Slovakia

E-mail: jana.kissova@euba.sk

ORCID: 0000-0002-4140-0890

doc. Ing. Mgr. Gabriela Dubcová, PhD.

University of Economics in Bratislava, Faculty of Business Management

Main Street No. 1, 85235 Bratislava, Slovakia

E-mail: gabriela.dubcova@euba.sk

ORCID: 0000-0001-5024-4335 